\title{
PEMBERIAN STATUS TERHADAP TERORIS BERDASARKAN KONVENSI JENEWA
}

\author{
Grace Natalia Kusuma1, Tiffany Setyo Pratiwi ${ }^{2}$ \\ ${ }^{1,2}$ Program Studi IImu Hubungan Internasional \\ Universitas Teknologi Yogyakarta, Indonesia \\ gracekusuma12@gmail.com, tiffanysubarman@gmail.com
}

\begin{abstract}
This research analyzes about the status given towards terrorists according to the Geneva Conventions as a source of International Humanitarian Law. This research is using descriptive qualitative methods and the sources for this research are from literature studies with secondary data sources such as books, articles, research journals, mass media, college notes, and internet sites. This research tries to describe that according to the Geneva Conventions, the status given to terrorists as perpetrators of crimes against humanity is unlawful combatant. In addition, the ICRC also gives unprivileged belligerent status to those who carry out their acts of terrorist as individuals and do not have assimilation with any terrorism groups. Acts of terrorism have also been proven to violate the Geneva Conventions, including Article 33 and Article 147 of the Geneva Convention IV 1949, Articles 51 and 85 of Additional Protocol I 1977, and Article 13 of Additional Protocol II 1977.
\end{abstract}

Keywords: Terrorism, Geneva Convention, International Humanitarian Law

\begin{abstract}
Abstrak
Tulisan ini merupakan analisis terkait pemberian status terhadap pelaku terorisme menurut Konvensi Jenewa sebagai salah satu sumber Hukum Humaniter Internasional. Penelitian ini menggunakan metode kualitatif deskriptif untuk menjelaskan praktik yang dilakukan oleh pelaku terorisme dan pelanggaran yang dilakukan terhadap Hukum Humaniter Internasional. Data yang digunakan dalam penelitian ini berasal dari studi literatur dengan sumber data sekunder seperti buku, artikel, jurnal penelitian, media massa, catatan perkuliahan, dan situs internet. Tulisan ini berusaha memaparkan bahwa menurut Konvensi Jenewa, status yang diberikan kepada teroris sebagai pelaku kejahatan kemanusiaan adalah unlawful combatant. Selain itu, ICRC juga memberikan status unprivileged belligerent kepada mereka yang menjalankan aksi terornya sebagai individu dan tidak memiliki asimilasi dengan kelompok terorisme. Tindak kejahatan terorisme juga terbukti melanggar Konvensi Jenewa, antara lainpasal 33 dan pasal 147 Konvensi Jenewa IV tahun 1949, pasal 51 dan 85 Protokol Tambahan I tahun 1977, dan pasal 13 Protokol Tambahan II tahun 1977.
\end{abstract}

Kata Kunci: Terorisme, Konvensi Jenewa, Hukum Humaniter Internasional

\section{PENDAHULUAN}

Praktik kejahatan terorisme telah banyak dilakukan di berbagai wilayah di dunia. Kejahatan ini tidak sedikit memakan korban, mulai dari yang luka-luka ringan, luka berat, menimbulkan kecacatan tubuh, atau bahkan hingga meninggal dunia. Terorisme dilakukan oleh kelompok atau individu tertentu untuk melakukan teror yang memunculkan rasa takut dalam suatu kelompok masyarakat, baik di tempat umum atau di tempat khusus. Tindak terorisme dilakukan dengan banyak metode, seperti: pembajakan, penculikan, penembakan, hingga pengeboman. Tujuan dari tindak ini berbeda-beda dari setiap pelakunya. Latar belakang motif tindakan dan latar belakang pelaku juga berbeda-beda dari setiap aksi yang dijalankan. 
Salah satu praktik kejahatan terorisme yang menyita perhatian dunia internasional adalah peristiwa 9/11. Serangan ini dilakukan pada 11 September 2001 dengan adanya pesawat penumpang United Airlines dan American Airlines yang diduga dibajak dan kemudian ditabrakkan ke gedung kembar pencakar langit yang menjadi kantor pusat World Trade Center di kota New York, Amerika Serikat. Pihak yang mengaku bertanggung jawab atas peristiwa ini adalah kelompok militan bernama Al-Qaeda yang pada saat itu dipimpin oleh Osama Bin Laden. Diketahui terdapat dua pesawat lain yang dibajak pada peristiwa dan dalam rangkaian aksi teror yang sama. Pesawat ke-tiga dibajak dan ditabrakkan ke gedung Pentagon di Virginia, Amerika Serikat yang menjadi markas dan kantor utama angkatan bersenjata milik Amerika Serikat. Pesawat ke-empat yang dibajak berhasil diambil alih kendali oleh penumpang yang mencoba melakukan perlawanan hingga pesawat akhirnya jatuh di lapangan wilayah Pennsylvania, Amerika Serikat yang sebelumnya ditargetkan di wilayah Washington DC yang menjadi pusat pemerintahan Amerika Serikat. Dari rangkaian peristiwa ini diketahui kurang lebih 2.996 jiwa meninggal dunia dan kurang lebih 6.000 orang diantaranya mengalami luka-luka. Gedung pencakar langit milik World Trade Center juga dikabarkan hancur selang dua jam penabrakkan terjadi (Wahyono 2019).

Aksi terorisme lain juga pernah dilakukan oleh seorang individu bernama Brendon Tarrant, pemuda berusia 28 tahun yang diketahui seorang warga negara Australia. Brendon Tarrant melakukan penembakan brutal pada hari Jumat tanggal 15 Maret 2019 di dua masjid yang berada di kota Christchurch, Selandia Baru. Penembakan dilakukan terhadap jamaah muslim yang sedang melakukan ibadah shalat Jumat di masjid Al-Noor dan masjid Linwood. Kejahatan terorsime ini menewaskan 49 orang jamaah kedua masjid. Diketahui pada saat melakukan aksi penembakan tersebut Brendon Tarrant sekaligus melakukan siaran live di sosial media pribadi miliknya selama 17 menit sehingga aksi itu terekam secara online dan menunjukan korban-korban yang terkena serangan. Aksi ini dikecam oleh masyarakat internasional dan menghadirkan simpati warga Selandia Baru yang kemudian banyak memberikan adanya karangan bunga di depan dua masjid yang menjadi target serangan sebagai wujud bela sungkawa. Brendon Tarrant diketahui adalah seorang pelaku rasisme dan pribadi yang menggaungkan anti-imigran, fakta tersebut diketahui dari jejak digital media sosial miliknya. Hal ini seturut dengan kenyataan bahwa jamaah kedua masjid yang menjadi target aksi teror Brendon Tarrant didominasi oleh warga imigran dan pengungsi yang berasal dari luar wilayah Selandia Baru (Primastika 2019).

Tindak terorisme menjadi kejahatan kemanusiaan dikarenakan dapat mengancam keselamatan manusia. Setiap negara memiliki aturan ataupun hukum nasional masing-masing terkait tindakan terorisme. Pelaku akan ditangkap dan dihukum sesuai dengan hukum yang berlaku. Salah satu negara yang pernah menjatuhi hukuman terhadap teroris ataupun pelaku teror adalah Indonesia. Peristiwa pengeboman yang terjadi di daerah Kuta, Bali pada 12 Oktober 2002 tersebut menargetkan dua tempat hiburan malam dan lokasi yang berdekatan dengan gedung konsulat Amerika Serikat di Bali. Dalam peristiwa ini diketahui kurang lebih 147 orang meninggal dunia dan 209 orang diantaranya mengalami luka. Tiga pelaku terorisme ini antara lain adalah Imam Samudra, Ali Ghufron, dan Amrozi yang akhirnya dijatuhi hukuman mati pada 9 November 2008 setelah menjalani hukuman penjara selama 6 tahun (Kurniawan 2008). 
Manusia pada hakikatnya memiliki hak asasi yang melekat pada diri mereka selama mereka hidup. Hak dasar ini melingkupi adanya hak untuk hidup dan bebas dari ancaman. Namun adanya aksi terorisme baik dari kelompok maupun individu dapat memberikan ancaman setiap manusia di muka bumi ini untuk mengalami serangan teror. Oleh karena itu diperlukan adanya hukum yang mengikat dalam menangani permasalahan terkait aksi terorisme. International Humanitarian Law atau hukum humaniter internasional dapat menjadi salah satu landasan hukum yang digunakan dalam melihat praktik kejahatan terorisme yang menargetkan manusia. Di dalam hukum humaniter internasional khususnya Konvensi Jenewa terkandung adanya aturan terkait status pihak yang terlibat dalam suatu kejahatan kemanusiaan ataupun praktik perang. Status ini dibedakan tergantung peran dari setiap pihak yang terlibat dimana nantinya status ini dapat digunakan dalam mengkategorisasikan halhal yang akan dihubungkan dengan pihak tersebut baik dari perlindungan maupun yang berkaitan dengan peradilan atau hukuman.

Dalam mengkaji mengenai pemberian status terhadap pelaku tindak terorisme menurut sumber hukum humaniter internasional yaitu Konvensi Jenewa, telah ada beberapa penelitian yang melakukan analisa terkait hal ini. Penelitian-penelitian tersebut digunakan oleh penulis sebagai adanya alat pembanding terhadap penulisan yang akan dilakukan. Pelaku tindak terorisme diakui sebagai aktor non negara dimana pelaku sebagian besar terikat dalam suatu kelompok terorisme yang terorganisir dengan adanya komando tertentu dari satu pihak. Seperti yang ditulis oleh Ivan Fantoni Purnomo dan Sri Lestari Rahayu (2016), dalam menjalankan war on terror sebagai tindak memerangi aksi terorisme pasca 9/11 di Amerika Serikat menurut Konvensi Jenewa status teroris merupakan penduduk sipil selama tidak terlibat dalam aksi teror dan mendapat status sebagai unlawfull belligerent apabila pelaku terlibat dalam aksi teror. Hal tersebut selaras dengan penulisan John C. Yoo (2016) yang menyatakan bahwa hak sipil menurut Konvensi Jenewa yang terdapat pada pelaku terorisme dapat dicabut sebab mereka justru melawan adanya normanorma dalam hukum humaniter internasional tersebut dengan melaksanakna aksi teror terhadap warga sipil hingga menyebabkan penderitaan yang berlebih.

Berdasarkan beberapa penelitian yang telah dipaparkan di atas, penulisan ini hendak meneliti terkait tulisan ini berusaha untuk memberikan analisis terkait status yang diberikan kepada teroris sebagai pelaku kejahatan kemanusiaan baik pelaku yang melangsungkan aksi sebagai kelompok ataupun individual menurut hukum humaniter internasional terutama Konvensi Jenewa. Pemberian status ini dapat digunakan dalam mengurai persoalan terkait pelanggaran hukum ataupun penjatuhan hukuman terhadap teroris sebagai pelaku kejahatan kemanusiaan. Penulisan ini juga mencoba melakukan analisa bagaimana Republik Indonesia sebagai salah satu negara yang melakukan ratifikasi terhadap Konvensi Jenewa dalam menerapkan prinsip-prinsip tersebut dalam hukum domestik Indonesia.

\section{KERANGKA PEMIKIRAN}

\section{Teori Hukum Humaniter Internasional}

International Humanitarian Law atau hukum humaniter internasional merupakan serangkaian aturan yang berisikan ketentuan-ketentuan dalam perang. Menurut Panitia Tetap Hukum Humaniter, Departemen Hukum dan Perundang-undangan mengartikan hukum humaniter internasional sebagai keseluruhan asas, kaidah, dan 
ketentuan internasional, baik tertulis maupun tidak tertulis yang mencakup hukum perang dan hak asasi manusia, bertujuan untuk menjamin penghormatan terhadap harkat dan martabat seseorang (Permanasari et al. 1999, 10). Menurut Daniel Thurer (2011), penerapan hukum humaniter saat ini jauh lebih kompleks dan beragam. Namun yang masih menjadi perhatian utama adalah penggunaan kekerasan baik yang dilakukan secara langsung maupun tidak langsung. Pendekatan hukum humaniter dalam tahap ini dapat dilihat dengan pendekatan idealis maupun realistis.

Di dalam hukum humaniter internasional terdapat prinsip penting yang terkandung di dalamnya. Prinsip ini disebut dengan Distinction Principle atau Prinsip Pembeda. Prinsip ini digunakan untuk membedakan adanya peran dari pihak yang terlibat. Terdapat dua kategori dalam prinsip ini, yaitu adanya status kombatan (combatant) dan penduduk sipil (civilian). Kombatan merupakan status yang diberikan terhadap golongan yang memiliki hak untuk terlibat dalam peperangan selama konflik terjadi, sedangkan penduduk sipil adalah golongan yang tidak terlibat di dalam peperangan yang berlangsung (Latuputty 2016, 4). Prinsip pembeda ini diperlukan untuk nantinya ketika perlu dilakukan perlindungan atau kegiatan yang berhubungan dengan hukum ataupun persidangan.

Salah satu yang menjadi landasan hukum humaniter internasional adalah Konvensi Jenewa. Pemahaman terkait hukum humaniter internasional dapat digunakan untuk menganalisis keberadaan pelaku tindak kejahatan terorisme dari kacamata Konvensi Jenewa yang memberikan adanya status atau kategorisasi. Hukum humaniter hadir dengan upaya untuk mengurangi ataupun menghindarkan penderitaan terlebih terhadap penduduk sipil.

\section{Konsep Perlindungan Sipil (Protection of Civilian)}

Perlindungan terhadap warga sipil merupakan konsep dasar yang dipraktikkan untuk menjunjung tinggi martabat warga sipil atas kaidahnya sebagai manusia. Perlindungan ini juga didasarkan atas adanya hak asasi manusia yang harus ditegakkan dalam situasi apapun. Konsep terkait perlindungan sipil diatur di dalam Konvensi Jenewa 1949 IV yang secara khusus menangani terkait perlindungan terhadap warga sipil dalam hukum humaniter internasional (Charinda 2018, 28). Perserikatan Bangsa Bangsa (PBB) melalui United Nations Peace Keeping juga menegakkan adanya konsep perlindungan terhadap warga sipil. Perlindungan warga sipil merupakan tanggung jawab yang mencakup seluruh bagian dari misi penjaga perdamaian, fungsi sipil, militer dan polisi. Dalam banyak kasus, misi penjaga perdamaian diizinkan untuk menggunakan berbagai cara yang diperlukan termasuk dengan adanya penggunaan kekerasan untuk mencegah atau menghadang ancaman kekerasan fisik terhadap warga sipil (Willmot et al. 2016, 12).

Perlindungan diberikan kepada warga sipil atas adanya ancaman yang sewaktu-waktu dapat datang. Ancaman tersebut dapat menargetkan keamanan warga dan keamanan dasar mereka sebagai manusia. Teror yang dijalankan untuk memberi rasa takut dan ancaman bahkan hingga mengancam nyawa warga sipil merupakan bentuk pelanggaran terhadap perlindungan warga sipil. Aksi teror sangat jelas menargetkan masyarakat yang tidak memiliki kemampuan cukup untuk melindungi diri. Ketakutan yang ditumbulkan oleh warga sipil merupakan tujuan utama dilakukannya tindak kejahatan terorisme. Efek lain seperti luka-luka hingga 
meregang nyawa merupakan aspek lain tergantung bentuk teror yang dilakukan oleh pelaku terorisme.

\section{METODE PENELITIAN}

Tulisan ini menggunakan metode kualitatif yang berbasis dengan data bukan angka dan disesuaikan dengan data yang berasal dari fakta terkait fenomena yang terjadi di lapangan. Penelitian kualitatif merupakan penelitian ilmiah berbasis data yang bertujuan memahami suatu fenomena dalam konteks sosial secara alamiah dengan mengedepankan proses interaksi yang mendalam antara peneliti dengan fenomena yang diteliti (Herdiansyah 2010, 9). Bentuk penelitian kualitatif ini dijelaskan secara deskriptif untuk menjelaskan bagaimana Konvensi Jenewa sebagai bagian dari hukum humaniter internasional memberikan kategorisasi status terhadap pelaku terorisme atau teroris.

Data yang diperoleh dari penelitian kualitatif akan diolah menjadi sumber dari suatu penulisan ilmiah. Sumber data terdiri dari dua jenis, yaitu sumber data primer dan sumber data sekunder (Herdiansyah 2010, 133). Dalam penelitian ini penulis menggunakan sumber data sekunder dimana pengumpulan datanya menggunakan metode studi literatur. Sumber data sekunder adalah data yang didapat dari aktivitas pengumpulan data yang telah diolah oleh penyedia data sehingga sifatnya tidak secara langsung namun memanfaatkan dari penelitian yang telah dilakukan sebelumnya (Herdiansyah 2010, 107). Studi literatur yang dilakukan dalam pengumpulan data di penulisan ini diambil dari buku, artikel, jurnal penelitian, media massa, catatan perkuliahan, dan situs internet yang berkaitan dengan penelitian yang dilakukan.

\section{PEMBAHASAN}

\section{Praktik Terorisme sebagai Ancaman terhadap Warga Sipil}

Terorisme merupakan tindak kejahatan yang menargetkan warga sipil dalam praktiknya. Menurut United Nations Security Council Resolution 1566, terorisme diartikan sebagai tindakan kriminal termasuk terhadap warga sipil yang dilakukan dengan maksud untuk menyebabkan kematian atau cedera tubuh yang serius baik dengan menyandera, dengan tujuan untuk memprovokasi keadaan teror di masyarakat umum atau dalam sekelompok orang atau orang-orang tertentu, mengintimidasi populasi atau memaksa pemerintah atau organisasi internasional untuk melakukan atau tidak melakukan tindakan apa pun (IOM 2010, 7).

Praktik terorisme memiliki sejumlah perubahan yang ditunjukkan dari adanya tren aksi masa ke masa. Praktik Terorisme Gelombang I terjadi sekitar tahun 1880an hingga tahun 1920an. Pada era ini aksi terorisme ditujukan untuk memenangkan reformasi politik sipil dari adanya pemerintah yang memimpin secara otoriter. Contoh aksi terorisme pada gelombang ini adalah Revolusi Rusia dimana tejadi teror dan pembunuhan terhadap keluarga Tsar Nicholas II oleh teroris politisi sayap kiri. Selanjutnya terdapat Terorisme Gelombang II yang berjalan di antara tahun 1920an hingga 1960an. Aksi teror pada gelombang ini didominasi oleh kelompok-kelompok yang berusaha memperjuangkan adannya kedaulatan nasional mereka. Contoh aksi terorisme gelombang ini adalah adanya Ireland Revolutionary Army (IRA) asal Irlandiayang melakukan aksi teror dalam menghadapi Pemerintah Inggris atas 
tuntutannya agar Inggris bergabung dengan Irlandia. Selain itu terdapat juga Front Liberation Nationale (FLN) asal Aljazair yang melakukan aksi teror dalam menghadapi pemerintahan kolonial Prancis dengan melakukan penembakan terhadap aparat kepolisian dan melakukan peledakan bom di kota Casbah. Terorisme Gelombang III terjadi pada tahun 1970an dimana aksi yang dilakukan pada gelombang ini didasarkan dengan adanya anggapan diri sebagai pembela kepentingan negara dunia lapisan ke-3 melawan kelompok kapitalis global. Contoh dari aksi di gelombang ke-tiga ini adalah kelompok Brigade Merah Italia yang memiliki landasan pemikiran menurut Marxisme dan berusaha mengeluarkan Italia dari NATO, aksinya dilakukan dengan melakukan penculikan terhadap anggota pemerintahan Perdana Menteri Italia Aldo Moro. Dari negara Jepang juga terdapat kelompok serupa bernama Brigade Merah Jepang yang melakukan penyerangan di Bandara Internasional Tel Aviv dan pembajakan pesawat Japan Airlines yang terbang menuju Belanda. Masa terbaru dari praktik terorisme terdapat pada Terorisme Gelombang IV yang terjadi pada tahun 2000an dengan adanya ideologi revolusioner dan adanya dorongan dari aspek relijius. Aksis teror di gelombang ini sudah tidak lagi memiliki ketakutan untuk menargetkan warga sipil sebagai target aksi teror. Dengan batasan-batasan negara yang semakin samar memunculkan adanya kelompok-kelompok teroris yang terorganisir dengan adanya sistem perekrutan dan pembentukan jaringan. Contoh kelompok terorisme dari gelombang ini adalah Al-Qaeda yang menjadi dalang dari serangan nine eleven di New York, Amerika Serikat. Selain itu terdapat juga kelompok jaringan teroris ISIS (Islamic State of Iraq and Syria) yang memiliki berbagai jaringan di negara-negara dunia dan telah melakukan banyak aksi teror seperti serangan di kota London, Inggris. (Abdulsalam 2017).

Dalam beberapa kasus, aksi terorisme dapat dikatakan sebagai tindakan politik yang kompleks dan ekstrim yang tumbuh dari adanya kombinasi berbagai latar belakang seperti adanya aspek budaya, ekonomi, politik dan psikologis (IOM 2010, 7). Bahkan dijelaskan pada gelombang ke-empat, terorisme mulai tumbuh dari adanya doktrin agama yang disalah gunakan untuk melakukan aksi teror. Doktrin ini bisa didapat dari berbagai sumber seperti mendatangi acara keagamaan, buku, akses melalui internet, ataupun rekruitmen yang dilakukan secara langsung dengan memberikan adanya pemahaman yang disampaikan oleh aktor yang memiliki kemampuan doktrinisasi berlandaskan keagamaan ataupun penyelamatan dunia.

Perkembangan dunia global yang semakin menghapus adanya batas-batas antar negara juga memungkinkan munculnya suatu kelompok-kelompok militan terorisme secara internasional. Perkembangan teknologi yang semakin memudahkan komunikasi juga membuat perkembangan anggota-anggota kelompok terorisme menjamur di beberapa negara lain, bahkan yang jauh dari negara pusat kelompok teroris tersebut berasal. Rekruitmen dapat dilakukan melalui sosial media yang saat ini sangat mudah diakses oleh banyak orang dengan berbagai latar belakang pendidikan dan ekonomi. Tidak semua orang mampu mengolah informasi yang didapatkan dari internet ataupun sosial media, sehingga seringkali kelompokkelompok terorisme ini memberikan jebakan ataupun iming-iming tertentu. Pelacakan kelompok terorisme bukan tidak terdeteksi, namun banyak dari mereka yang menggunakan sosial media yang memiliki fitur pesan rahasia seperti telegram. Sehingga ketika dideteksi pesan terkait penyebaran informasi dapat hilang dari data ataupun sistem ponsel. Rekruitmen juga dapat dijalankan secara nasional sehingga 
banyak kelompok terorisme yang memiliki sub-kelompok di negara lainnya namun tetap dengan satu komando dari negara asal kelompok tersebut.

Berikut adalah beberapa daftar jaringan kelompok teroris internasional berserta tahun berdirinya (Rollins 2019, 2).

Tabel 1. Daftar Jaringan Besar Kelompok Terorisme Internasional

\begin{tabular}{|c|l|}
\hline Tahun Berdiri & \multicolumn{1}{|c|}{ Nama Kelompok Jaringan Terorisme } \\
\hline \multirow{4}{*}{1997} & Abu Nidal Organization (ANO) \\
\cline { 2 - 2 } & Abu Sayyaf Group (ASG) \\
\cline { 2 - 2 } & HAMAS \\
\cline { 2 - 2 } & Hizballah \\
\hline 1999 & Al-Qaeda \\
\hline 2004 & Islamic State of Iraq and the Levant (ISIL) \\
\hline 2013 & Boko Haram \\
\hline \multirow{2}{*}{2014} & Ansar Al-Shari'a \\
\cline { 2 - 2 } & Islamic State of Iraq and Syria (ISIS) \\
\hline
\end{tabular}

Sumber : Congressional Research Service, 2019 (edited)

Kelompok-kelompok teroris ini diketahui memiliki suatu jaringan yang kuat dan menjalankan aksinya berdasarkan satu komando dan jaringan ini tersebar luas di negara-negara lain. Anggota kelompok yang berasal dari negara lain juga membentuk jaringan internal guna melakukan rekrutmen terhadap anggota penerusnya. Tidak jarang kelompok terorisme ini mengundang warga negara lainnya untuk bergabung di negara pusat dengan memberikan sejumlah penawaran jaminan hidup yang layak, bahkan tawaran tersebut berhubungan dengan kepercayaan mereka terkait imbalan surgawi apabila mereka berkenan untuk tergabung dalam kelompok tersebut.

Perkembangan aksi terorisme dari generasi ke generasi menunjukkan bagaimana target yang menjadi sasaran teror juga berubah. Aksi teror dimulai dari generasi ke-IV menargetkan warga sipil baik secara umum ataupun khusus untuk dijadikan target serangan teror. Dominasi aspek relijius pada generasi ini membuat pola target yang dibentuk oleh teroris dapat terlihat. Serangan ditujukan kepada mereka yang terkesan memiliki pandangan ataupun kepercayaan yang bersebrangan dengan apa yang mereka anut dan dijadikan landasan mereka melakukan aksi teror. Korban dari aksi teror juga mengalami peningkatan dalam kurun waktu tertentu. Pada tahun 2014 korban meninggal akibat serangan terorisme di Iraq mencapai angka 21.000, di Nigeria 29.000, di Afghanistan 33.000, dan sisanya di seluruh wilayah dunia mencapai angka 11.000 (IEP 2019, 35). Pada tahun 2019, Afghanistan menjadi negara yang mengalami dampak tertinggi dari serangan terorisme dengan angka 7.379 kematian dan peningkatan sebesar $59 \%$ dari tahun sebelumnya (IEP 2019, 36).

Dari banyak aksi serangan terorisme yang memakan banyak korban dan mengancam adanya perlindungan sipil menuntut adanya aturan ataupun hukum yang dapat digunakan untuk melakukan peradilan terhadap pelaku tindak terorisme. Hukum ini diupayakan agar dapat mengurangi aksi-aksi yang merampas adanya hak 
asasi manusia untuk tetap hidup dan dapat digunakan untuk memutuskan penjatuhan hukum terhadap pelaku terorisme. Berdasarkan prinsip perlindungan terhadap warga sipil baik yang menjadi korban ataupun yang sewaktu-waktu dapat terancam atas keberadaan kelompok terorisme ini, diperlukan landasan yang sah dan menjadi acuan terkait peraturan hukum yang ada. Selain itu, hukum tersebut juga diperlukan untuk memberikan kategorisasi ataupun penyematan status terhadap pelaku terorisme dalam memberikan adanya ketentuan-ketentuan lain yang nantinya akan dijatuhkan kepada pelaku aksi tindak kejahatan terorisme. Salah satu hukum yang dapat diadaptasi ataupun digunakan dalam memberikan ketentuan ini adalah hukum humaniter internasional, terutama Konvensi Jenewa.

\section{Konvensi Jenewa melihat Aksi Terorisme sebagai Hukum Humaniter Internasional}

Menurut Jean Pictet, hukum humaniter internasional memiliki dua sumber hukum utama, antara lain hukum Den Haag dan Hukum Jenewa (Pictet 1985, 1). Dalam menganalisis terkait kategorisasi status pelaku tindak terorisme, penelitian ini akan menggunakan salah satu sumber hukum humaniter internasional yang berlaku di seluruh dunia, yaitu Hukum Jenewa. Hukum Jenewa terdiri atas perjanjian-perjanjian yang menjadi bagian dari hukum humaniter internasional. Konvensi Jenewa 1949 I, Konvensi Jenewa 1949 II, Konvensi Jenewa 1949 III, Konvensi Jenewa 1949 IV, Protokol Tambahan 1977 I, dan Protokol Tambahan 1977 II menjadi dasar utama dari Hukum Jenewa (Permanasari et al. 1999, 32). Menurut common article 2 menjelaskan bagaimana Konvensi Jenewa dapat diterapkan dalam situasi dan kondisi tertentu. Konvensi Jenewa dapat berlaku di seluruh peristiwa perang yang diumumkan secara luas ataupun di setiap pertikaian atau konflik bersenjata yang mungkin dapat timbul antara dua atau lebih pihak, meskipun keadaan perang sedang tidak diakui oleh salah satu pihak yang terlibat. Sehingga Konvensi ini berlaku pada situasi (Permanasari et al. 1999, 34-35) :

1. Perang yang diumumkan;

2. Pertikaian bersenjata sekalipun keadaan perang tidak diakui;

3. Dalam hal pendudukan sebagian atau seluruhnya sakali pun pendudukan tersebut tidak menemui perlawanan.

Serangan terorisme yang dilakukan di negara tertentu menunjukkan adanya perlawanan terhadap kedaulatan negara dengan adanya tindak teror ataupun ancaman yang diberikan. Warga sipil sebagai bagian dari kedaulatan ditujukan menjadi target dari serangan yang ada. Aksi terorisme yang memberikan ketakutan ataupun serangan terhadap warga sipil dapat diakui sebagai pertikaian bersenjata sekalipun keadaan perang tidak diakui, atau dapat dikategorikan dalam keadaan damai. Namun, ketika serangan tersebut dijalankan, negara sebagai entitas tertinggi akan melakukan perlawanan sebagai wujud perlindungan sipil yang harus dijalankan oleh negara.

Di dalam Konvensi Jenewa dijelaskan adanya status-status yang diberikan terhadap pihak yang turut dalam kondisi-kondisi dimana Konvensi Jenewa dapat diterapkan. 
Tabel 2. Kategori Status Pihak yang Terlibat dalam Konflik Menurut Konvensi Jenewa

\begin{tabular}{|l|l|}
\hline \multicolumn{1}{|c|}{ Status } & \multicolumn{1}{c|}{ Keterangan } \\
\hline Kombatan & $\begin{array}{l}\text { Status hukum seseorang yang memiliki hak untuk terlibat } \\
\text { dalam peperangan selama konflik bersenjata berlangsung. }\end{array}$ \\
\hline Warga Sipil & $\begin{array}{l}\text { Pihak yang tidak mengambil bagian dalam konflik dan } \\
\text { memiliki perlindungan khusus. }\end{array}$ \\
\hline Belligerents & $\begin{array}{l}\text { Pihak yang bersengketa (pemberontak) yang mandiri secara } \\
\text { politis dan militer. }\end{array}$ \\
\hline $\begin{array}{l}\text { Prisioners of War } \\
\text { (POWs) }\end{array}$ & $\begin{array}{l}\text { Seseorang yang ditahan oleh pihak musuh baik kombatan } \\
\text { maupun non-kombatan. }\end{array}$ \\
\hline
\end{tabular}

Sumber : Permanasari et al. 1999. (edited)

Dalam melihat status kombatan, menurut pasal 43 dan 44 Protokol I tahun 1977 status ini diatur kembali sesuai dengan legalitas pihak yang terlibat dalam konflik. Kombatan adalah pihak yang memiliki hak untuk terlibat dalam konflik dan apabila tertangkap dapat diberlakukan sebagai tawanan perang atau Prisioners of War. Dapat dikatakan mereka merupakan anggota angkatan perang yang sah dan memiliki landasan hukum dan termasuk ke dalam lawful combatant (Haryomataram 1984, 72-73). Untuk kombatan dapat dikatakan sah harus memenuhi syarat dalam menjalankan armed force, yaitu (Haryomataram 1984, 80):

1. adanya organisasi;

2. adanya disiplin;

3. komando yang bertanggung jawab atas ditaatinya ketentuan hukum perang.

Apabila ketiga syarat tersebut telah dipenuhi, maka pihak yang terlibat diakui sebagai lawful combatant menurut hukum humaniter internasional. Untuk kombatan yang tidak memenuhi syarat dalam menjalankan armed force diberikan status sebagai unlawful combatant atau kombatan yang tidak sah menurut hukum humaniter internasional. Sebagai kombatan yang tidak sah menurut hukum humaniter internasional, maka akan lebih berat atas risiko yang kapan saja bisa didapat apabila mereka sewaktu-waktu ditangkap. Mereka tetap tunduk terhadap penangkapan dan penahanan serta dapat diadili atau dijatuhi hukuman oleh pengadilan khusus militer atas tindakan atau aksi yang dilakukan (Permanasari et al. 1999, 107).

Pelaku terorisme ketika dikaitkan dalam hukum humaniter internasional, terutama Konvensi Jenewa, maka dapat diberikan status sebagai unlawful combatant. Status ini didasari atas tidak terpenuhinya syarat dalam mereka menjalankan armed force dalam bentuk teror. Dari tiga syarat yang ada, mereka hanya memenuhi syarat pertama sebagai organisasi. Kelompok terorisme jelas memiliki struktur sebagai organisasi yang memiliki pemimpin dan jajaran tertentu. Namun dalam organisasi tersebut tidak ditemui adanya disiplin dan komando yang bertanggung jawab atas ditaatinya ketentuan hukum perang. Hal ini terbukti dengan aksi teror yang ditargetkan kepada warga sipil atau civilian yang dilindungi secara khusus oleh hukum humaniter internasional ataupun hukum perang. Perlindungan sipil secara khusus diatur dalam hukum humaniter internasional yang tertera di dalam Konvensi Jenewa IV tahun 1949 tentang Perlindungan Sipil. 


\section{Ayat 1 Pasal 3 Konvensi Jenewa IV tahun 1949 menjelaskan:}

"Persons taking no active part in the hostilities, including members of armed forces who have laid down their arms and those placed' hors de combat ' by sickness, wounds, detention, or any other cause, shall in all circumstances be treated humanely, without any adverse distinction founded on race, colors, religion or faith, sex, birth or wealth, or any other similar criteria.

To this end, the following acts are and shall remain prohibited at any time and in any place whatsoever with respect to the above-mentioned persons:

a) violence to life and person, in particular murder of all kinds, mutilation, cruel treatment and torture;

b) taking of hostages;

c) outrages upon personal dignity, in particular humiliating and degrading treatment;

d) the passing of sentences and the carrying out of executions without previous judgment pronounced by a regularly constituted court, affording all the judicial guarantees which are recognized as indispensable by civilized peoples."

Ketika perlindungan sipil diterapkan dalam kondisi dimana aksi terorisme terjadi, hal ini melanggar adanya hukum humaniter sehingga pelaku aksi teror yang tidak memiliki komando bertanggung jawab terbukti melanggar hukum humaniter internasional. Unlawful combatant dalam tahap ini dapat ditangkap dan diadili sesuai dengan praktik kejahatan kemanusiaan yang telah dilakukannya.

Pemberian status teroris sebagai pelaku kejahatan teror dengan unlawful combatant memunculkan adanya gagasan lain yang memberikan pendapat bahwa tidak seluruh teroris atau pelaku teror tergabung dalam organisasi atau kelompok terorisme. Banyak dari aksi yang dijalankan berdasarkan kepentingan individu seperti yang dilakukan oleh Brendon Tarrant atas aksi teror dan penembakannya di wilayah Christchurch, Selandia Baru. Selain itu serangan teror yang dilakukan oleh individu juga terjadi di Texas oleh pemuda bernama Patrick Crusius yang melakukan penembakan dan menewaskan 22 pengunjung pasar modern Walmart. Connor Stephen Betts juga pelaku teror individu yang menewaskan 10 korban setelah melakukan penembakan di salah satu bar kota Ohio, Amerika Serikat (Utomo 2019). Menurut International Committee of the Red Cross, organisasi kemanusiaan yang memiliki mandat secara internasional untuk menegakkan dan menjalankan hukum humaniter internasional menjelaskan kategori pihak seperti ini dapat disebut sebagai unprivileged belligerent. Meskipun hukum humaniter internasional tidak secara spesifik menjelaskan pola unprivileged belligerent, ICRC memahami kondisi pihak yang mengambil bagian seperti ini sangat mungkin terjadi. Unprivileged belligerent digunakan untuk merujuk pada seseorang yang secara langsung berpartisipasi dalam konflik bersenjata namun tidak memiliki atau telah kehilangan status kombatan mereka. Akibatnya mereka tidak berhak diperlakukan atas hak istimewa kombatan, yaitu adanya kekebalan dari penuntutan atas tindakan perang yang sah menurut hukum humaniter internasional dan tidak mendapat manfaat dari tahanan status perang (POW) jika mereka jatuh ke tangan musuh (ICRC n.d.).

Kelompok militan terorisme yang dapat diberikan status sebagai unlawful combatant ataupun spesifikasi unprivileged belligerentdapat dikenakan peradilan atas pelanggaran hukum humaniter internasional dengan merampas adanya perlindungan sipil. Hukum humaniter internasional melarang tindakan terorisme yang paling umum dan biasa dipraktikan, bahkan jika dilakukan untuk alasan yang sah. 
Bentuk kejahatan terorisme yang melanggar hukum humaniter internasional antara lain, serangan terhadap warga sipil seperti yang diatur dalam Ayat 2 Pasal 51 Protokol Tambahan I tahun 1977 dan Ayat 2 Pasal 13 Protokol Tambahan II tahun 1977, serangan tidak pandang buluh seperti yang diatur dalam Ayat 4 dan 5 Pasal 51 Protokol Tambahan I tahun 1977, tindakan atau ancaman yang tujuan utamanya adalah untuk menyebarkan teror di kalangan penduduk sipil seperti yang diatur dalam Ayat 2 Pasal 51 Protokol Tambahan I tahun 1977 dan Ayat 2 Pasal 13 Protokol Tambahan II tahun 1977, dan tindakan "terorisme" yang ditujukan terhadap warga sipil dalam kekuatan musuh seperti yang diatur dalam Pasal 33 Konvensi Jenewa IV tahun 1949.Sehingga, anggota kelompok terorisme seperti Al-Qaeda dan milisi Taliban tidak secara hukum berhak untuk mati berserta hak-hak khusus dan perlindungan yang diatur untuk tentara profesional atau lawful combatant (Yoo 2016, 137-139). Dalam kebanyakan kasus, tindakan semacam ini dianggap sebagai kejahatan perang yang harus dituntut secara universal yang juga diatur dalam Pasal 147 Konvensi Jenewa IV tahun 1949, Pasal 85 Protokol Tambahan I tahun 1977, dan Pasal 8 Statuta Pengadilan Kejahatan Internasional (International Criminal Court) (ICRC n.d.).

\section{Terorisme di Indonesia}

Dalam undang-undang RI Nomor 5 Tahun 2018 memberikan definisi terorisme adalah perbuatan yang menggunakan kekerasan atau ancaman kekerasan yang menimbulkan suasana teror atau rasa takut secara meluas, yang dapat menimbulkan korban yang bersifat massal, dan/atau menimbulkan kerusakan atau kehancuran terhadap objek vital yang strategis, lingkungan hidup, fasilitas publik, atau fasilitas internasional dengan motif ideologi, politik, atau gangguan keamanan. Pidana penjara seumur hidup, atau pidana mati (setkab.go.id). Indonesia adalah negara yang sangat berkomitmen dalam penanggulangan terorisme. Pada tingkat internasional, Indonesia merujuk kerangka penanggulangan terorisme PBB, seperti selalu aktif mengikuti perkembangan kerjasama dengan United Nations Counters Terrorism Implementation Task Force (CTITF) dan implementasi empat pilar United Ntaions Global Counter-Terrorism Strategy (UNGCTS). Di tingkat nasional, penanggulangan terorisme diatur dalam UU Nomor 15 Tahun 2003 tentang Penanggulangan Terorisme dan UU Nomor 9 Tahun 2013 tentang Pencegahan dan Pemberantasan Tindak Pidana Pendanaan Terorisme (kemlu.go.id). Berikut adalah beberapa kasus teror di Indonesia.

Tabel 3. Daftar Peristiwa Teror di Indonesia dalam Jangka Waktu 4 Tahun Terakhir

\begin{tabular}{|c|l|}
\hline Tahun & \multicolumn{1}{|c|}{ Peristiwa } \\
\hline 2016 & Bom Thamrin, Jakarta \\
\hline 2016 & Bom Mapolresta, Solo \\
\hline 2016 & Bom Molotov, Kalimantan Barat dan Kalimantan Timur \\
\hline 2016 & Bom Sarinah, Jakarta \\
\hline 2017 & Bom Terminal Kampung Melayu, Jakarta \\
\hline
\end{tabular}


Vol.3, No. 2 (Agustus 2020)

doi: https://doi.org/10.36341/jdp.v3i2.1347

\begin{tabular}{|l|l|}
\hline 2018 & Bom Gereja Surabaya \\
\hline 2018 & Bom Rusunawa, Sidoarjo \\
\hline 2019 & Bom Pos Lebaran, Sukoharjo \\
\hline 2019 & Bom Polrestabes, Medan \\
\hline
\end{tabular}

Sumber : Badriyanto 2018 (edited)

Sebagai negara yang turut menjunjung tinggi hak asasi manusia serta mengupayakan perlindungan manusia dalam kondisi konflik, Indonesia turut melakukan ratifikasi terhadap Konvensi Jenewa 1949 sebagai sumber Hukum Humaniter Internasional. Ratifikasi ini dilakukan oleh Indonesia pada 30 September 1958 pasca kedatangan ICRC ke Indonesia (ICRC n.d.). Ratifikasi terhadap hukum internasional yang berkaitan dengan hukum humaniter dan hukum tentang hak asasi manusia tidak hanya dilakukan terhadap Konvensi Jenewa 1949, namun juga terhadap hukum lain seperti Convention on the Elimination of all Forms of Discrimination against Women (13 September 1984), Convention on the Rights of the child (5 September 1990), Convention against Torture and Other Cruel, Inhuman or Degrading Treatment or Punishment (28 Oktober 1998), dan International Convention on the Elimination of all Forms of Racial Discrimination (25 Juni 1999). Hukum-hukum tersebut kemudian menjadi bagian dari hukum domestik yang berlaku di Indonesia (International Business Publications 2015, 97).

Hukum domestik yang dibentuk oleh Indonesia dalam menangani terkait aksi terorisme adalah Undang-Undang No. 5 Tahun 2018 tentang pemberantasan tindak pidana terorisme. Dalam undang-undang ini diatur terkait praktik terorisme dari hulu ke hilir. Perencanaan ataupun perserikatan kelompok terorisme bahkan sudah dianggap berpotensi mengancam keamanan dan kesejahteraan masyarakat, bangsa dan negara, serta perdamaian dunia. Hal ini seturut dengan upaya Indonesia sebagai negara yang berusaha melaksanakan perlindungan terhadap warga sipil yang sewaktu-waktu dapat menjadi target dari aksi teror. Pasal 6 undang-undang tersebut menyatakan bahwa pelaku aksi terorisme dapat dijatuhi hukuman dengan pidana penjara paling singkat 5 (lima) tahun dan paling lama 20 (dua puluh) tahun, pidana penjara seumur hidup, atau bahkan pidana mati. Hukuman tersebut disesuaikan dengan aksi teror yang dapat merenggut hak asasi manusia dimana terdapat hak dasar setiap insan yaitu hak untuk hidup.

\section{KESIMPULAN}

Tindak kejahatan teror yang dilakukan terhadap warga sipil dengan melakukan serangan, menebar ketakutan, serangan, penculikan, pembajakan, hingga pengeboman yang dapat menyebabkan seseorang mengalami luka-luka atau bahkan meninggal dunia merupakan tindak kejahatan yang melanggar hak asasi manusia dan dilarang oleh hukum humaniter internasional. Pelaku teror diberikan status unlawful combatant dengan tidak memiliki hak atas perlindungan hukum humaniter yang menaungi para pihak dalam konflik. Bagi pelaku yang menjalankan aksi tanpa terlibat dalam kelompok asimilasi terorisme tertentu juga tetap mendapat status pelaku kejahatan sebagai unprivileged belligerentmenurut ICRC meskipun mereka pada dasarnya adalah warga sipil yang memiliki perlindungan. 
Hak atas perlindungan warga sipil dapat dihapuskan atas mereka akibat adanya perlindungan sipil terhadap warga lain yang dapat menjadi sasaran ataupun target dari tindak terorisme. Tindakan terorisme terbukti melanggar hukum humaniter internasional yang terkandung dalam Pasal 51 Protokol Tambahan I tahun 1977, Pasal 13 Protokol Tambahan II tahun 1977, Pasal 33 Konvensi Jenewa IV tahun 1949, Pasal 147 Konvensi Jenewa IV tahun 1949, Pasal 85 Protokol Tambahan I tahun 1977, dan bahkan juga melanggar aturan di dalam Pasal 8 Statuta Pengadilan Kejahatan Internasional.

\section{REFERENSI}

Abdulsalam, Husein. (2017). "Empat Generasi dalam Sejarah Terorisme." Tirto.ID, 12 September. https://tirto.id/empat-generasi-dalam-sejarah-terorisme-cwpb.

Badriyanto. (2018). "7 Serangan Teroris di Indonesia Tiga Tahun Terakhir." Okezone, 14 Mei. https://nasional.okezone.com/read/2018/05/14/337/1897942/7serangan-teroris-di-indonesia-tiga-tahun-terakhir-nomor-5-diwarnai-drama.

Charinda, Donna Exsanti. (2018). Penerapan Konvensi Jenewa 1949 IV Tentang Perlindungan Sipil dalam Sengketa Wilayah Khasmir 2010-2014. Lampung : Universitas Lampung.

Haryomataram. (1984). Hukum Humaniter. Jakarta : Rajawali Press.

Herdiansyah, Haris. (2010). Metode Penelitian Kualitatif untuk IImu-ilmu Sosial. Jakarta: Salemba Humanika.

International Business Publications. (2015). Indonesia Criminal Justice System Laws, Regulations and Procedures Handbook : Volume 1 Strategic Information and Regulations. Washington DC : International Business Publications.

International Committee of The Red Cross. "Treaties, States Parties and Commentaries." https://ihldatabases.icrc.org/applic/ihl/ihl.nsf/vwTreatiesByCountrySelected.xsp?xp_cou ntrySelected=ID\&nV=4.

International Organization for Migration. (2010). "International Terrorism and Migration. Geneva : International Organization for Migration."

Institute for Economic \& Peace. (2019). "Global Terrorism Index 2019 : Measuring the Impact of Terrorism."http://visionofhumanity.org/reports.

Kurniawan, Sigit. (2008). "Eksekusi Mati Tiga Terpidana Kasus Bom Bali."Elshinta.com,

November.https://elshinta.com/news/192132/2019/11/09/eksekusi-mati-tigaterpidana-kasus-bom-bali

Kementerian Luar Negeri Indonesia. (2019). Indonesia dan Upaya Penanggulan Terorisme, daring https://kemlu.go.id/portal/id/read/95/halaman_list_lainnya/indonesia-danupaya-penanggulangan-terorisme

Latuputty, Marcelino Heryanto. (2016). Status Hukum Pihak-pihak yang Bertikai dalam Konflik Bersenjata di Suriah Berdasarkan Hukum Humaniter Internasional. Yogyakarta : Universitas Atma Jaya.

Permanasari, Arlina., Aji Wibowo, Fadillah Agus, Achmad Romsan, Supardan Mansyur, dan Michael G. Nainggolan. (1999). Pengantar Hukum Humaniter. Jakarta : International Committee of the Red Cross. 
Pictet, Jean. (1985). Development and Principles of International Humanitarian Law. Dordrecht : Martinus Nijhoff Publisher.

Primastika, Widia. (2019). "Penembakan di Selandia Baru : Terorisme atau Penembakan Massal?" Tirto.ID, 16 Maret. https://tirto.id/penembakan-diselandia-baru-terorisme-atau-penembakan-massal-djEz.

Purnomo, Ivan Fatoni dan Sri Lestari Rahayu. (2016). "Status Teroris dalam War on Terror (Kajian Berdasarkan Hukum Humaniter Internasional)". Jurnal Belli ac Pacis, Vol. 2, 1 Juni.

Rollins, John W. (2019). Foreign Terrorist Organization Washington DC : Congressional Research Service.

Thurer, Daniel. (2011). International Humanitarian Law. Den Haag : Hague Academy of International Law.

Utomo, Ardi Priyatno. (2019). "Kaleidoskop : 5 Aksi Teror yang Terjadi di Dunia Sepanjang 2019". Kompas, 30 Desember. https://internasional.kompas.com/read/2019/12/30/21451221/kaleidoskop-5aksi-teror-yang-terjadi-di-dunia-sepanjang-2019?page=all.

UU Nomor 5 Tahun (2018), daring https://sipuu.setkab.go.id/PUUdoc/175528/UU\%20Nomor\%205\%20Tahun\%20 2018.pdf

Wahyono. (2019). "Serangan Teror Paling Brutal yang Pernah Dilakukan di Dunia." SindoNews, 6 Juni. https://international.sindonews.com/berita/1409010/45/serangan-teror-palingbrutal-yang-pernah-dilakukan-di-dunia.

Willmot, Haidi., Ralph Mamiya, Marc Weller, dan Scott Sheeran. (2016). Protection of Civilians. Oxford : Oxford University Press.

Yoo, John C. (2016). "The Status of Soldiers and Terrorists under the Geneva Convention". Journal of The University of Tennessee : 135-150. http://chinesejil.oxfordjournals.org/ 